\title{
CEO Duality and Firm Value: Evidence from Mexico *
}

\author{
Juan Pablo Dávila-Velásquez \\ Professor of Finance and Control Departament, INALDE Business School - Universidad de La Sabana, Chía - Colombia \\ juan.davila@inalde.edu.co (D) https://orcid.org/0000-0002-6791-7003

\section{Diógenes Lagos-Cortés} \\ Researcher of Family Business Research Group, INALDE Business School - Universidad de La Sabana, Chía, Colombia \\ diogenes.lagos@inalde.edu.co (D) https://orcid.org/0000-0002-847/-4726
}

A B S T R A C T

Regulators and corporate governance activists are lobbying companies to eliminate the CEO duality; however, the effectiveness of this recommendation is questioned given that empirical evidence has found conflicting results. This document studied the effects of the CEO's duality on the value of the company in a sample of I04 Mexican companies that were publicly traded between 2000 and 2013. For this, different regression models were estimated using the ordinary least squares technique. The firm value was measured through Tobin's $Q$ and ROA. Empirical results showed that there is no relationship between CEO duality and value after controlling for board characteristics such as size and independence.

KEYWORDS

Corporate governance; CEO duality; firm value; agency theory; stewardship theory

JEL Classification

MIO, G32, G34

\section{Dualidad del CEO y valor de la empresa: Evidencia de México}

Los reguladores y los activistas del gobierno corporativo están presionando a las empresas para que eliminen la dualidad del CEO, sin embargo, la efectividad de esta recomendación es cuestionada dado que la evidencia empírica ha encontrado resultados contradictorios. Este documento estudió los efectos de la dualidad del CEO en el valor de la empresa en una muestra de 104 empresas mexicanas que cotizaron públicamente entre 2000 y 2013. Para esto, se estimaron diferentes modelos de regresión utilizando la técnica de mínimos cuadrados ordinarios. El valor de la empresa se midió a través de la $\mathrm{Q}$ de Tobin y el ROA. Los resultados empíricos mostraron que no existe una relación entre la dualidad del CEO y el valor de la empresa después de controlar las características de la junta, como el tamaño y la independencia.

Palabras clave

Gobierno corporativo; dualidad del CEO; valor de la empresa; teoría de la agencia; teoría de la mayordomía

Clasificación JEL

MIO, G32, G34

Recibido: 21/03/2020 Aceptado: 06/06/2020

\footnotetext{
* This paper is part of the research project entitled Corporate Governance and Firm Value: Evidence from Colombia and México. The financing institution was INALDE Business School - University of La Sabana.

Este es un artículo Open Access bajo la licencia BY-NC-SA (http://creativecommons.org/licenses/by-nc-sa/4.0/) Published by Universidad Libre - Cali, Colombia.
} 


\section{Dualidade do CEO e valor da empresa: evidências do México}

Os reguladores e os activistas do governo das sociedades estão a pressionar as empresas para eliminar a dualidade do Presidente da Comissão Executiva, no entanto, a eficácia desta recomendação é posta em causa, uma vez que provas empíricas têm encontrado resultados contraditórios. Este documento estudou os efeitos da dualidade dos CEO no valor da empresa numa amostra de 104 empresas mexicanas negociadas publicamente entre 2000 e 20I3. Para tal, foram estimados diferentes modelos de regressão utilizando a técnica dos mínimos quadrados comuns. $O$ valor da empresa foi medido pelo $Q$ de Tobin e o ROA. Os resultados empíricos mostraram que não existe relação entre a dualidade do CEO e o valor da empresa depois de controlar para características do conselho como a dimensão e a independência.

Palavras-chave Governança corporativa; dualidade do CEO; valor comercial; teoria da agência; teoria da administração

Classificação JEL

MIO, G32, G34

\section{Introduction}

The corporate scandals of the late 90's and the early 00 's have given corporate governance research and practice increased attention (Claessens \& Yurtoglu, 2013). Regulation (Sarbanes-Oxley and OECD Principles for Corporate Governance) has been developed to improve governance practices worldwide (Aguilera \& Jackson, 2010; OCDE, 2017). Most of it has been based on agency theory and focused on defining guidelines for the board of directors (Hinna \& Monteduro, 2017). Corporate governance literature has been focused mainly on UK and US companies, with very little research on emerging markets such as Mexico, where regulation and the economic environment are different. Research on the board of directors as a corporate governance mechanism is plentiful, however most of the literature on boards of directors has focused on board size and composition. Little research has been done on other board characteristics, most notably the importance of the CEO/ chairman duality.

On the other hand, Mexico's business environment has evolved over the last three decades. It has changed from a government-controlled environment ( 80 's) to an open market dominated by private ownership (90's and 00's) (Price, Román, \& Rountree, 20II). This dramatic change, along with the size of the Mexican consumer market (population of more than 100 million) has attracted large amounts of foreign investment thus increasing the need for corporate governance in companies. Mexico is the second largest economy in Latin America, just behind Brazil and way ahead of Colombia and Argentina. Its model of Corporate Governance, as with the rest of Latin American countries, is closely related to the Continental European model. However it presents unique features such as a small capital market (La Porta, Lopez-de-Silanes, Shleifer, \& Vishny, 2000b), weak protection of shareholders (La Porta et al., 2000b), a weak legal system (Klapper \& Love, 2004) and high ownership concentration in founding families (La Porta, Lopez-deSilanes, Shleifer, \& Vishny, 2000a). Literature on corporate governance in Mexico is scarce. There is research only in governance as a whole (Husted \& Serrano, 2002), governance recommendations and reforms (Machuga \& Teitel, 2007; Price et al., 20II), ownership (Klapper \& Love, 2004; La Porta et al.,2000a). Mexico implemented a new governance law in 2006, which followed Sarbanes-Oxley principles of limiting board size and defining guidelines that promote board independence.

The purpose of this study is to analyze the relationship between CEO duality and performance in an emerging market environment. Empirical evidence is mixed on the relationship between CEO duality and value (Dalton, Daily, Ellstrand, \& Johnson, 1998; Dey, Engel, \& Liu, 20II), while some authors support agency theory on the negative impact of duality on value (Christensen, Kent, \& Stewart, 2010; Dahya, Garcia, \& Van Bommel, 2009; Dechow, Sloan, \& Sweeney, 1996; Dogan, Elitas, Agca, \& Ögel, 2013; Faleye, 2007; Jermias \& Gani, 2014; Tuggle, Sirmon, Reutzel, \& Bierman, 2010) others support stewardship theory by arguing for a positive relationship between CEO duality and firm value (Amaral-Baptista, Klotzle, \& de Melo, 20II; Corbetta \& Salvato, 2004; Vera \& Ugedo, 2005; Yang \& Zhao, 20l4). There is even evidence of no relationship between CEO duality and firm value (Adams, Almeida, \& Ferreira, 2005; Amba, 2013; Braun \& Sharma, 2007; Chen, Lin, \& Yi, 2008; Elsayed, 2007; Lam \& Lee, 2008; Meyer, 2006; Pucheta-Martinez, 2015; Raluca-Georgiana, 2013). 
This paper adds to literature by providing evidence of the impact of CEO duality as a corporate governance variable on firm value with data from Mexico. It also provides evidence of the relationship between board characteristics, family ownership and governance reforms and firm value for an emerging market such as Mexico. This study is valuable for shareholders and directors in Mexico. Through better governance firms should be able to increase their access to external financing, by decreasing risk and lowering their cost of capital, their value increases and they should be able to attract more investors (Claessens \& Yurtoglu, 2013). It is also valuable for regulators in their quest to assess whether governance laws based on the Sarbanes-Oxley Act have a positive impact on value in emerging markets where economic and legal environments are different. The paper used data of listed companies from the Mexican Stock Exchange for the 2000-20I 2 period since it allowed the author to have enough observations from before and after the new stock market law of 2006 was adopted, thus enabling assessment of its impact on value. Empirical results showed that there is no relationship between CEO duality and value after controlling for board characteristics such as size and independence.

This paper is organized as follows: Section I presents the literature review and explains the hypothesis, Section 2 reviews the research methodology, describing data and statistics, Section 3 presents the results and discusses the findings, while Section 4 concludes and explains research limitations.

\section{Literature review and hypothesis development}

\subsection{Corporate governance and firm value in Mexico}

Mexico's business environment has evolved over the last three decades. It has changed from a government-controlled environment ( 80 's) to an open market dominated by private ownership (90's and 00's) (Price et al., 2011). This dramatic change, along with the size of the Mexican consumer market (population of more than 100 million) has attracted large amounts of foreign investment thus increasing the need for corporate governance in companies. Mexico is the second largest economy in Latin America, just behind Brazil and way ahead of Colombia and Argentina. Its model of Corporate Governance, as with the rest of Latin American countries, is closely related to the Continental European model. However it presents unique features such as a small capital market (La Porta et al., 2000b), weak protection of shareholders (La Porta et al., 2000b), a weak legal system
(Klapper \& Love, 2004) and high ownership concentration in founding families (Klapper \& Love, 2004; La Porta et al., 2000a).

Research on corporate governance for Mexico is limited. Some studies on corporate governance for Mexico have focused on the impact of governance recommendations and guidelines on value. While Machuga \& Teitel (2007) and Price et al. (20II) agree on the lack of evidence of a positive impact on firm value due to the implementation of such recommendations, Chong \& Lopez-De-Silanes (2006) provides evidence that when companies in Mexico implemented differentiating governance tools effectively, they were able to get lower costs of capital and thus increased their value.

\subsection{Corporate governance, CEO duality and} firm value

Stewardship theory presents an interesting contrast to agency theory by studying the conditions in which agents act in the principals best interest rather than on self-interest (Schillemans, 2013). Davis, Schoorman, \& Donaldson (1997) suggests that the perspective changes from one of control (agency theory) to one of focusing on the premises under which stewardship works. The word steward goes back to monarchical times where a person serves and represents the monarchy, and thus is not expected to act as independent agent with interests different than the ones of the principal. Schillemans (2013) summarizes various contrasting assumptions between agency theory and stewardship theory by suggesting that stewards are motivated by collective goals (intrinsic motivation, i.e. reputation, realization, acknowledgment) rather by self-interest (extrinsic motivation, i.e. financial incentives). He also suggests that agents require more control while stewards are more autonomous.

Stewardship theory's biggest differences with agency theory in the corporate governance context lie in both the treatment of CEO duality and board independence. CEO duality refers to the fact that the CEO and the chairman of the board of directors are the same person (Rechner \& Dalton, 1991). Stewardship theory argues for a unified, stronger leadership and a more insider oriented board, where agents are aligned with shareholders and advise is more important than control (Davis et al., 1997; Donaldson \& Davis, 1991). Agency theory, on the other hand argues for no duality and for more independent boards since both these characteristics provide better control and thus better shareholder protection (Fama, 1980; Fama \& Jensen, 1983). In general, corporate governance codes recommend avoiding CEO duality. However, empirical evidence about the relationship between CEO duality and firm value 
presents mixed results (Dalton et al.. 1998; Dey et al. 20II). On the one hand, the agency theory suggests the concentration of power in the CEO allows the achievement of individual objectives at the expense of the interests of the shareholders (Jensen, 1993). In the same way, limits the board's main responsibility of monitoring the CEO. Thus, argues for board independence as a better mechanism for monitoring management, meaning that by separating these two roles management entrenchment is controlled and boards become more independent and thus create value (Peng, Zhang, \& Li, 2007). Previous studies support a negative relationship between CEO duality and value generation (Christensen et al., 2010; Dahya et al., 2009; Dechow et al., 1996; Dogan et al., 2013; Faleye, 2007; Jermias \& Gani, 2014; Tuggle et al., 2010)

On the other hand, stewardship theory argues that a unified leadership (CEO and Chairman of the Board being the same person) improves efficiency organizational (Bhagat \& Black, 2002; Daily \& Dalton, 1993; Donaldson \& Davis, 1991; Peng et al., 2007). The word steward goes back to monarchical times where a person serves and represents the monarchy, and thus is not expected to act as an independent agent with interests different than the ones of the principal. Following this line of thought, managers that act as stewards create value just by representing the principals properly (Davis et al., 1997; Donaldson \& Davis, 1991). The organizational structure that optimizes "steward type" managers is one where managers have total authority over the company. CEO duality, a common leadership structure found in Mexico is an example of such structure. CEO duality is supported by stewardship theory since it argues for a stronger more united leadership where interests are aligned and where advice more than control is needed (Davis et al., 1997; Donaldson \& Davis, 1991). Previous studies support a positive relationship between CEO duality and value generation (Amaral-Baptista et al., 2011; Corbetta \& Salvato, 2004; Peng et al., 2007; Vera \& Ugedo, 2005; Yang \& Zhao, 2014).

Finally, other studies have found that the relationship between CEO duality and performance is neutral (Adams et al., 2005; Amba, 2013; Braun \& Sharma, 2007; Chen et al., 2008; Elsayed, 2007; Lam \& Lee, 2008; Meyer, 2006; Pucheta-Martinez, 2015; Raluca-Georgiana, 2013). The lack of agreement in the literature makes it interesting to investigate whether there is a significant relationship between CEO duality and the firm value in Mexico. This generates three hypotheses:

$\mathrm{HIa}$ : There is a positive and significant relationship between CEO duality and the firm value in Mexico.
$\mathrm{HIb}$ :There is no significant relationship between CEO duality and the firm value in Mexico.

$\mathrm{HIc}$ :There is a significant negative relationship between the CEO duality and the firm value in Mexico.

\section{Methodology}

\section{I. Sample}

This study used data from 101 Mexican listed companies with 914 observations from the period between 2000 and 2013. The reasons behind using this sample are: (I) Corporate Governance Law was published in 2006 which helps in testing the impact of such law by using pre and post 2006 periods; (2) The advantage of taking such a large sample of years provides more observations and thus providing robustness to the results. Board data (Duality, Size, Composition) was obtained from individual company's annual reports. All financial figures were obtained from the Mexican Stock Exchange information system and validated from annual reports. Information on the governance law was obtained from the Mexico Stock Exchange webpage.

\subsection{Variables and research model}

The following variables were used in the analysis: The dependent variable was the firm value, measured through the TOBIN'S_Q. This study also used ROA as dependent variable to provide robustness to the model. The independent variable was CEO_DUALITY. Finally, to ensure that the results will not be addressed by the heterogeneity of the companies, it was controlled by variables that the literature has associated with firm value. These control variables commonly found in the literature are BOARD SIZE, INDEPENDENT, FAMILY, adoption of a corporate governance law (LAW_2006), GROWTH, SALES, LIQUIDITY as well as the lagged value of the dependent variable which is expected to be significant because a previous positive and significant TOBIN'S_Q might affect positively for the next period.

The usage of the lagged dependent variable on the right hand side of the equation as an independent variable has been used in the literature (e.g. Haniffa \& Hudaib, 2006). Most governance literature argues for either a positive or negative relationship between mechanisms such as board size, board independence, and ownership structure with firm value. Since it is expected for these variables to have a relationship to firm value, they will be controlled for isolate CEO duality's impact on value. Table I shows the detailed definition of the variables. 
Table I.

Variable definition of research model

\section{Variable}

\begin{tabular}{|c|c|c|}
\hline TOBIN'S_Q & $=$ & $\begin{array}{l}\text { It was defined as the relationship between market price and book value of company assets. It was } \\
\text { calculated as equity market value }+ \text { book value of liabilities/replacement book value of assets (Coles, } \\
\text { Daniel, \& Naveen, 2008). }\end{array}$ \\
\hline ROA & $=$ & $\begin{array}{l}\text { Proxy for economic performance. It was calculated as net profit/ book value of assets (Jara, López- } \\
\text { Iturriaga, San-Martín, \& Saona, 2019). }\end{array}$ \\
\hline CEO_DUALITY & $=$ & $\begin{array}{l}\text { This is a dummy variable and can be defined as } 1 \text {, when CEO and chairman of the board are the same } \\
\text { person and } 0 \text { when they are not (Tang, 2017). }\end{array}$ \\
\hline BOARD_SIZE & & Number of board members (Cavaco, Challe, Crifo, Rebérioux, \& Roudaut, 2016). \\
\hline INDEPENDENT & $=$ & $\begin{array}{l}\text { It was defined as the proportion of independent directors within the board. It was calculated as number of } \\
\text { independent directors/total number of directors (Cavaco et al., 2016). }\end{array}$ \\
\hline FAMILY & $=$ & $\begin{array}{l}\text { Dummy variable that takes the value of } 1 \text { when the company is considered to be family owned and takes } \\
\text { value } 0 \text { when it is not. This study considered that a family-owned a company when one family held more } \\
\text { than } 35 \% \text { of the shares (Anderson, Mansi, \& Reeb, 2003). }\end{array}$ \\
\hline LAW_2006 & $=$ & $\begin{array}{l}\text { It is a dummy variable in the model with } 1 \text { being all observations after the publication and implementation } \\
\text { of the law and } 0 \text { being all observations before the implementation of the law. }\end{array}$ \\
\hline GDP_GROWTH & $=$ & $\begin{array}{l}\text { This is a control variable since overall performance by the Mexican economy can have a direct effect on } \\
\text { the value of Mexican companies. The information comes from the database provided by the World Bank. }\end{array}$ \\
\hline SALES & $=$ & $\begin{array}{l}\text { Proxy for firm size. It was calculated as the natural logarithm of sales (Boubakri, Guedhami, \& Saffar, } \\
\text { 2016). }\end{array}$ \\
\hline LIQUIDITY & $=$ & $\begin{array}{l}\text { The liquidity index measures the amount of times that a certain stock of a company is traded within a } \\
\text { certain period. The index is generated for the Mexican Stock Market and takes value from } 1 \text { to } 10,1 \\
\text { being the minimum value given to stocks with low liquidity and } 10 \text { the maximum value given to stocks } \\
\text { with high levels of liquidity. }\end{array}$ \\
\hline YEAR & $=$ & Dummy variable to identify the year of the analysis, 2001-2012. \\
\hline
\end{tabular}

\section{Definition}

Source: Own elaboration

Results for an initial model that did not take into account time-varying effects are presented in column (a) in Table 6. After controlling for time-varying effects by including year dummy variables, a final model was developed (column $\mathrm{h}$ in Table 6):

$$
\begin{aligned}
& \text { TOBIN'S_Q }=\text { CONSTANT }+\beta_{1} \text { CEO_DUALITY }+ \\
& \beta_{2} \text { BOARD_SIZE }+\beta_{3} \text { INDEPENDENT }+\beta_{4} \text { FAMILY }+ \\
& \beta_{5} \text { LAW_2006 }+\beta_{6} \text { GDP_GROWTH }+ \\
& \beta_{7} \text { SALES }+\beta_{8} \text { LIQUIDITY }+\beta_{9} \text { LAG_TOBIN'S_Q }+ \\
& \beta_{10} \text { Y } 2001+\beta_{11 \ldots 21} \text { YEAR }+\varepsilon
\end{aligned}
$$

\section{Results and discussion}

\section{I. Descriptive Statistics}

Table 2 shows the summary of the descriptive statistics for the variables in the model. Table 3 presents the difference of means tests that were made for each variable to prove whether there is statistical significance in the difference between groups (before and after law). This will be useful to determine whether board's and firm's characteristics change significantly between periods. Average TOBIN'S_Q for the period is 1.76 with a standard deviation of $3.2 \mathrm{I}$. It $\mid$ rises from an average of 1.27 for the period before the implementation of the law to 2.06 for the period after the implementation (Table 3). A two-sample $t$ test with equal variances show the difference of 0.79 to be statistically significant at $\operatorname{Pr}(\mathrm{T}>\mathrm{t})=0.0000$. This means that company's value increased after the law was implemented. CEO DUALITY presents an average of 0.44 with a standard deviation of 0.50 . It has an average value of 0.44 before law implementation and 0.43 after ( $\underline{\text { Table } 3}$ ). It can be assumed the small difference that could exist between the two periods is not statically significant with a $\operatorname{Pr}(\mathrm{T}>\mathrm{t})=0.79$. This shows that on average Mexican companies maintained their leadership structures before and after the law.

BOARD_SIZE showed an average of II.7 directors with a standard deviation of 3.66. This variable changed from a minimum of 4 to a maximum of 21 members. The mean grew from II.6I (2000 to 2006) to II.76 (2007 to 20I3) (See table 18). A two-sample $t$ test with equal variances showed the difference of 0.15 which is statistically insignificant. INDEPENDENT, measured by the percentage of independent directors showed an average of 0.45 with a standard deviation of 0.18 ; these results range from a minimum of $11 \%$ to a maximum of $100 \%$. The average percentage of independent directors changes from 0.42 for 
data prior to 2006 to 0.47 for data after 2006 (Table 3). A two-sample $t$ test with equal variances showed the difference to be statistically significant at $\operatorname{Pr}(T>t)=0.00$. This means that the percentage of independents changed significantly between the two above-mentioned periods.

FAMILY has a mean of 0.68 in the sample, indicating that $68 \%$ of the observations for the companies studied are family owned. This is consistent for emerging economies where markets are small and ownership is concentrated (Klapper \& Love, 2004; La Porta et al., 2000a). This result doesn't change much between periods. It has a value of 0.71 before and 0.66 after the implementation of governance regulations ( Table 3 ). This difference is not significant with a $\operatorname{Pr}(T>t)=0.10$, meaning that ownership structure did not change during the sample period.

Tables 2 and 3 also contain the descriptive statistics for the control variables. GDP_GROWTH has a mean of 2.45 that changed from 3.09 to 2.06 between periods (Table 3 ).
This difference, as can be expected by the changes in GDP growth after the financial crisis of 2008, turned out to be significant in the $t$-test with $\operatorname{Pr}(T>t)=0.0000$. SALES, the proxy variable for firm size, presents an average of 15.94 with a standard deviation of 1.76 going from a minimum value of 9.2 to a maximum of 20.3. It goes from an average of 15.8I (2000 to 2006) to an average of 16.0I (2007 to 2013) ( Table 3). A two-group t test with equal variances showed the difference to be statistically significant at $\operatorname{Pr}(\mathrm{T}>\mathrm{t})=0.08$. These results show an important increase (statistically significant) on the size of listed firms, which is consistent with Mexican economic growth over this period. Finally, LIQUIDITY presents an average of 5.87 with a standard deviation of 2.19. It goes from an average of 6.32 (2000-2006) to an average of 5.59 (2007-2013) (Table 3). The difference is significant with a $\operatorname{Pr}(\mathrm{T}>\mathrm{t})=0.00$ and can be once again explained by the consequences that arose from the 2008 crisis, in which the stock markets from all over the world lost credibility and trading volumes decreased.

Table 2.

Descriptive statistics for the complete sample

\begin{tabular}{lccccc}
\hline & Observations & Mean & Standard Deviation & Minimum & Maximum \\
\hline TOBIN'S_Q & 914 & 1.76 & 3.21 & 0.01 & 57.78 \\
CEO_DUALITY & 914 & 0.44 & 0.50 & 0.00 & 1.00 \\
BOARD_SIZE & 914 & 11.70 & 3.66 & 4.00 & 0.11 \\
INDEPENDENT & 914 & 0.45 & 0.18 & 0.00 & 1.00 \\
FAMILY & 914 & 0.68 & 0.47 & 0.00 & 1.00 \\
LAW_2006 & 914 & 0.62 & 2.49 & -4.70 & 1.00 \\
GDP_GROWTH & 914 & 2.45 & 1.76 & 9.21 & 5.30 \\
SALES & 914 & 15.94 & 2.19 & 0.01 & 9.66 \\
LIQUIDITY & 914 & 5.87 & & & 20.32 \\
\hline
\end{tabular}

Source: Own elaboration

Table 3.

Difference of means Test Governance Law

\begin{tabular}{lccccc}
\hline & Mean (0) & Standard Deviation & Mean (1) & Standard Deviation & Pr \\
\hline TOBIN'S_Q & 1.27 & 1.50 & 2.06 & 3.87 & 0.00 \\
CEO_DUALITY & 0.44 & 0.50 & 0.43 & 0.50 & 0.79 \\
BOARD_SIZE & 11.61 & 3.67 & 11.76 & 3.66 & 0.55 \\
INDEPENDENT & 0.42 & 0.17 & 0.47 & 0.18 & 0.47 \\
FAMILY & 0.71 & 0.45 & 0.66 & 3.06 & 0.10 \\
GDP_GROWTH & 3.09 & 1.83 & 2.06 & 1.79 & 0.00 \\
SALES & 15.81 & 1.69 & 16.01 & 5.00 & 0.08 \\
LIQUIDITY & 6.32 & 1.98 & 5.59 & 2.26 & 0.00 \\
\hline
\end{tabular}

Notes: Difference of mean test for the variable LAW_2006 in which Mean (0) Information prior to corporate governance implementation and Mean (I): Information after corporate governance implementation.

Source: Own elaboration 
Table 4 provides evidence of the differences between companies with different leadership structures (duality and no duality). This table presents the results of a t-test taking CEO_DUALITY as the fixed variable. TOBIN'S_Q (proxy for value), did not change significantly between groups. It changed from I.6I to 1.95 respectively having a non-significant difference at $\operatorname{Pr}(T>t)=0.11$. This shows that firm value does not change significantly between two different leadership structures. On the other hand, variables such as BOARD_SIZE, SALES, FAMILY and LIQUIDITY had different results. For these variables the difference between means was statistically significant. BOARD_SIZE for nondual companies has an average of I I.32 while board size for dual companies has an average of 12.19 ; this difference $(0.87)$ is statistically significant which shows that companies with duality have larger boards. SALES, the proxy for firm size also present significant differences, while non-duality companies show an average of 16.03 dual companies show an average of $15.8 \mathrm{I}$ meaning that companies with CEO duality tend to be smaller than non-duality ones. Companies without CEO duality tend to be on average less concentrated. Lastly, dual companies show a significantly lower liquidity index (5.70) than non-dual companies (5.99) which means that during the period from 2000 to 2013 dual company stocks were traded less than non-duality companies.

The study checked for the multi-collinearity among the different variables. As can be seen in Table 5 there is no abnormally high correlation between variables thus providing validity to regression results.

Table 4.

Difference of mean test CEO Duality

\begin{tabular}{lccccc}
\hline & Mean (0) & SD & Mean (1) & Standard Deviation & Pr \\
\hline TOBIN'S_Q & 1.61 & 2.55 & 1.95 & 3.90 & 3.87 \\
BOARD_SIZE & 11.32 & 3.45 & 12.19 & 0.11 & 0.00 \\
INDEPENDENT & 0.46 & 0.18 & 0.44 & 0.45 & 0.20 \\
FAMILY & 0.65 & 0.48 & 0.72 & 2.77 & 0.04 \\
GROWTH & 2.47 & 2.66 & 2.43 & 1.74 & 0.84 \\
SALES & 16.03 & 1.76 & 15.81 & 2.11 & 0.06 \\
LIQUIDITY & 5.99 & 2.24 & 5.70 & 0.05 \\
\hline
\end{tabular}

Notes: Includes information of the difference of mean test for the variable CEO duality in which Mean (0) Information for companies without CEO duality and Mean (I): Information for companies with CEO duality

Source: Own elaboration

Table 5.

Correlation matrix for the complete sample

\begin{tabular}{|c|c|c|c|c|c|c|c|c|c|}
\hline & 1 & 2 & 3 & 4 & 5 & 6 & 7 & 8 & 9 \\
\hline 1 TOBIN'S_Q & 1 & & & & & & & & \\
\hline 2 BOARD_SIZE & -0.062 & 1 & & & & & & & \\
\hline 3 INDEPENDENT & 0.003 & 0.526 & 1 & & & & & & \\
\hline 4 CEO_DUALITY & 0.047 & 0.116 & 0.019 & 1 & & & & & \\
\hline 5 LAW_2006 & 0.115 & 0.020 & 0.138 & -0.002 & 1 & & & & \\
\hline 6 SALES & -0.008 & 0.338 & 0.176 & -0.065 & 0.057 & 1 & & & \\
\hline 7 FAMILY & 0.073 & 0.029 & -0.037 & 0.069 & -0.054 & 0.248 & 1 & & \\
\hline 8 GDP_GROWTH & -0.028 & -0.037 & -0.021 & -0.030 & -0.163 & -0.033 & -0.007 & 1 & \\
\hline 9 LIQUIDITY & 0.020 & 0.266 & 0.246 & -0.055 & -0.160 & 0.579 & 0.117 & -0.019 & 1 \\
\hline $10 \mathrm{ROA}$ & -0.258 & 0.001 & 0.023 & 0.076 & -0.019 & 0.107 & -0.017 & 0.032 & 0.051 \\
\hline
\end{tabular}




\subsection{Regression results}

Results from the original model's regression reveal no relationship between any of the governance related variables and firm value except for law implementation. CEO_DUALITY, BOARD_SIZE, INDEPENDENT and FAMILY showed no significant relationships at any level while LAW_2006 turned out to be positively and significantly related to firm value, however when controlling for time varying effects (see column h) this positive relationship disappeared. Results of the regression of the adopted model, presented in column (h) on Table 6 showed an R-Squared of $0.441 \mathrm{I}$, suggesting that $44.1 \mathrm{I} \%$ of the variations of TOBIN'S_Q of the sample are explained by the independent variables.

CEO_DUALITY, the dummy variable for leadership structure was positive $(0.145)$ but not significant therefore leading to the conclusion that in the Mexican case, CEO duality does not have any impact on firm value supporting hypothesis $\mathrm{HI}$. This shows that the division between CEO and chairman of the board does not have any relevance to the creation of value. Second, results show that there is no linear relationship between TOBIN'S_Q and BOARD_SIZE (non-significant coefficient of -0.017 ). The low magnitudes and the $p$-values are conclusive and show that the number of members in the board of directors does not appear to have any impact in firm's value.Third, percentage of independents (INDEPENDENT), the proxy for board independence was positive at 0.062 but again non-significant providing evidence of board independence not being related to value. It is important to report that results on governance variables (CEO duality, board size and board independence) and their relationship with value do not support agency theory which might mean that agency theory is not applicable for emerging markets. Fourth, FAMILY, the dummy variable that showed whether the company was family owned or not was also positive but non-significant (coefficient of 0.214 ). This provides evidence to conclude that family ownership is not an important variable in generating value for Mexican firms. Two of the other control variables, GDP GROWTH and LAG_TOBIN'S_Q, show significant relationships with TOBIN'S_Q. These results provide validity to the model since it can be expected for both of them to be related to value. The GDP_GROWTH coefficient is positive with a 0.126 and Lag (I year) of Tobin's Q, 0.649 , both having a level of significance of $1 \%$. LIQUIDITY had a positive but non-significant relationship while SALES was negative but small in magnitude and non-significant.

\subsection{Robustness tests}

Different regressions were run to test for robustness. Table 6 summarizes all the complementary regressions that were made from columns (b) to (g). Regression (b) eliminates LAG_TOBIN'S_Q coefficient and thus leading to a decrease in the R-squared of near $37 \%$. Regression (c) takes as control variable of GDP_GROWTH a dummy variable that takes the value of one when GDP_GROWTH is over zero and, zero if not, this shows very similar results as the ones presented in the first column. The next two regressions ( $d$ e) take ROA or the logarithmic value of $R O A+I$ as independent variables leading to a low R-squared. Regressions on columns $(\mathrm{f})$ and $(\mathrm{g})$ changed the dependent variable, with ROA replacing TOBIN'S_Q in the equation. Under these scenarios not a single variable is significant thus giving validity to the model.

It is important to mention the possibility of reverse causation between firm value (Tobin's Q) and duality, meaning that good or bad results might drive shareholders to either change the leadership structure of the company. In order to check against reverse causation a complementary regression was run with TOBIN'S_Q as an independent variable and duality as the dependent variable (column (i) of Table 6) and no significant relationship was found between these variables.

\section{Discussion and conclusions}

Regulators and corporate governance activists are lobbying companies to eliminate the CEO duality, however, the effectiveness of this recommendation is questioned given that empirical evidence has found conflicting results, for instance, about the relationship between duality and firm performance. Two theories have been used to support these empirical results. On the one hand, agency theory states that independent boards provide better monitoring of management and thus create value (Anderson \& Reeb, 2004; Fama, 1980; Fama \& Jensen, 1983; Krivogorsky, 2006). A dual leadership promotes management entrenchment and management behavior (such as appointment of nonqualified board members) that could hamper the effectiveness of monitoring done by the Board (Fama \& Jensen, 1983; Jensen \& Meckling, 1976). On the other hand, stewardship theory contradicts agency theory by arguing that duality increases accountability and is less costly (Bhagat \& Black, 2002; Daily \& Dalton, 1993; Donaldson \& Davis, 1991).

This paper studied the effects of CEO duality on firm value in Mexico in a sample of 104 Mexican companies that were publicly traded between 2000 and 2013. The firm value was measured through Tobin's $Q$ and ROA. Since other governance variables such as board independence and size might have an impact on value they were used as control variables in the study. Results show that CEO duality has no impact on firm value, thus showing that different leadership 
Table. 6

Regression Results

\begin{tabular}{|c|c|c|c|c|c|c|c|c|c|}
\hline & (a) & (b) & (c) & (d) & (e) & (f) & (g) & (h) & (i) \\
\hline & TOBIN'S_Q & TOBIN'S_Q & TOBIN'S_Q & TOBIN'S_Q & TOBIN'S_Q & ROA & ROA & TOBIN'S_Q & $\begin{array}{l}\text { CEO } \\
\text { DUALITY }\end{array}$ \\
\hline \multirow[t]{2}{*}{ Constant } & 0.069 & 2.144 & -0.862 & 0.699 & 1.487 & -0.565 & -0.328 & 0.108 & 0.704 \\
\hline & 1.131 & 2.795 & 1.151 & 1.016 & 0.952 & 0.385 & 0.251 & 1.114 & 0.434 \\
\hline \multirow[t]{2}{*}{ BOARD_SIZE } & -0.018 & -0.062 & -0.013 & -0.070 & -0.072 & -0.003 & -0.003 & -0.017 & $0.020^{*}$ \\
\hline & 0.023 & 0.050 & 0.023 & 0.046 & 0.040 & 0.004 & 0.003 & 0.022 & 0.013 \\
\hline \multirow[t]{2}{*}{ INDEPENDENT } & -0.053 & 0.494 & -0.009 & 0.653 & 0.459 & 0.062 & 0.057 & 0.062 & -0.020 \\
\hline & 0.698 & 1.522 & 0.694 & 1.544 & 1.265 & 0.069 & 0.048 & 0.232 & 0.244 \\
\hline \multirow[t]{2}{*}{ CEO_DUALITY } & 0.139 & 0.390 & 0.134 & 0.545 & 0.471 & 0.060 & 0.038 & 0.145 & \\
\hline & 0.235 & 0.585 & 0.231 & 0.494 & 0.414 & 0.046 & 0.030 & 0.232 & \\
\hline \multirow[t]{2}{*}{ LAW_2006 } & $0.520^{* * *}$ & $0.920^{\star * *}$ & $0.460^{* * *}$ & $0.860^{* * *}$ & $0.810^{* * *}$ & -0.025 & -0.022 & -0.182 & -0.026 \\
\hline & 0.128 & 0.239 & 0.119 & 0.210 & 0.186 & 0.034 & 0.018 & 0.176 & 0.052 \\
\hline \multirow[t]{2}{*}{ LOG_SALES } & -0.014 & -0.111 & -0.006 & -0.015 & -0.055 & 0.038 & 0.023 & -0.010 & -0.032 \\
\hline & 0.082 & 0.207 & 0.081 & 0.084 & 0.084 & 0.028 & 0.018 & 0.079 & 0.034 \\
\hline \multirow[t]{2}{*}{ FAMILY } & 0.229 & 0.558 & 0.220 & 0.475 & 0.374 & -0.033 & -0.024 & 0.214 & 0.106 \\
\hline & 0.195 & 0.476 & 0.195 & 0.430 & 0.383 & 0.058 & 0.036 & 0.188 & 0.103 \\
\hline \multirow[t]{2}{*}{$\begin{array}{l}\text { GDP } \\
\text { GROWTH }\end{array}$} & $0.110^{* * *}$ & -0.003 & 0.025 & 0.005 & $0.010^{\star * *}$ & 0.003 & 0.000 & $0.120^{* * *}$ & 0.002 \\
\hline & 0.0031 & 0.012 & 0.051 & 0.015 & 0.008 & 0.003 & 0.001 & 0.036 & 0.003 \\
\hline \multirow[t]{2}{*}{ LIQUIDITY } & 0.040 & 0.132 & $0.650^{\star * *}$ & 0.142 & 0.108 & 0.004 & 0.002 & 0.040 & -0.016 \\
\hline & 0.051 & 0.108 & 0.033 & 0.111 & 0.120 & 0.006 & 0.003 & 0.048 & 0.024 \\
\hline \multirow[t]{2}{*}{$\begin{array}{l}\text { LAG_} \\
\text { TOBIN'S_Q }\end{array}$} & $0.640^{* * *}$ & & $1.300^{\star \star *}$ & & & & & $0.640^{* * *}$ & 0.006 \\
\hline & 0.035 & & 0.413 & & & & & 0.331 & 0.007 \\
\hline \multirow[t]{2}{*}{ ROA } & & & & -2.559 & & & & & \\
\hline & & & & 2.714 & & & & & \\
\hline \multirow[t]{2}{*}{ LOG_ROA+1 } & & & & & 2.051 & & & & \\
\hline & & & & & 4.976 & & & & \\
\hline \multirow[t]{2}{*}{ LAG_ROA } & & & & & & & $0.480^{* * *}$ & & \\
\hline & & & & & & & 0.056 & & \\
\hline YEAR & & & & & & & & Included & \\
\hline \multirow[t]{2}{*}{ TOBIN'S_Q } & & & & & & & & & 0.005 \\
\hline & & & & & & & & & 0.007 \\
\hline $\mathrm{R} 2$ & 0.411 & 0.034 & 0.418 & 0.095 & 0.053 & 0.050 & 0.279 & 0.441 & 0.044 \\
\hline
\end{tabular}

Notes: Six regressions are show in which $(h)$ is conclusive regression and the others are complementary. $(f)$ and $(g)$ correspond to regression using ROA as dependent variable. (i) uses duality as dependent looking for reverse causation. While (a), (b), (c), (d) and (e) are without using years dummy variables, without the lagged value of Tobin's Q using GDP_GROWTH dummy, using ROA as independent variable and using the lagged value of ROA+I, respectively. Standard errors below coefficients (* $p r>0.1$; *** $p r>0.05$; *** $p r>0.0$ I)

Source: Own elaboration 
structures do not affect value within an emerging market context such as Mexico. This suggests that in the Mexican context, both the role of the CEO and the chairman of the board are not as efficient in generating value. Given that there is ample evidence on the role of the CEO and the board of directors in the generation of value, it is proposed that these roles be reinforced to guarantee adequate protection for investors.

Finally, most of the governance variables included in this research do not appear to have a definite relationship with value for emerging markets therefore further research on this topic is needed. Further research can be conducted on different governance variables (such as management ownership, block holder ownership, compensation, board dynamics and specific family characteristics - generation, involvement) and their relationship with value to be able to assess whether governance is really important in emerging markets. These variables were not included in this research and might provide deeper knowledge for academics, investors and regulators.

\section{Conflict of interests}

The authors have no conflicts of interest to declare

\section{References}

I. ADAMS, Renée; HEITOR, Almeida; FERREIRA, Daniel. Powerful CEOs and their impact on corporate performance. In:The Review of Financial Studies. 2005. vol. I8, no. 4, p. I 403-I 432. https://doi.org//0.1093/rfs/hhi030

2. AGUILERA, Ruth; Jackson, GREGORY. Comparative and international corporate governance. In: The academy of management annals. 2010 . vol. 4, no. I, p. 485-556. https://doi.org// $0.1080 / 19416520.2010 .495525$

3. AMARAL-BAPTISTA, Marcio; CABÚS, Marcelo; CAMPELO, Maria. CEO duality and firm performance in Brazil: Evidence from 2008. In: Revista pensamento contemporâneo em administração. 201 I. vol. 5, no. I, p. 24-37. https://doi.org/10.127/2/rpca.v5il.18

4. AMBA, Sekhar. Does CEO duality enhance firms business performance? Empirical evidence from Bahrain. In: International journal of business and social science. 2013. vol. 4, no. 6, p. 88-91.

5. ANDERSON, Ronald; MANSI, Sattar; REEB, David. Founding family ownership and the agency cost of debt. In: Journal of financial economics. 2003. vol. 68, no. 2, p. 263-285.

https://doi.org//0.1016/s0304-405x(03)00067-9

6. ANDERSON, Ronald; REEB, David. Board composition: Balancing family influence in S\&P 500 firms. In: Administrative science quarterly. 2004. vol. 49 , no. 2 , p. 209-237.

https://doi.org//0.2307/4| 31472
7. BHAGAT, Sanai; BLACK, Bernard. The non-correlation between board independence and long-term firm performance. In: Journal of corporate law. 2002. vol. 27, p. 23 I-273. https://doi.org//0.2139/ssrn.133808

8. BOUBAKRI, Narjess; GUEDHAMI, Omrane; SAFFAR, Walid. Geographic location, foreign ownership, and cost of equity capital: Evidence from privatization. In: Journal of corporate finance. 2016. vol. 38, p. 363-38I. https://doi.org/10.1016/j.jcorpfin.2016.02.004

9. BRAUN, Michael; SHARMA, Anurag. Should the CEO also be chair of the board? An empirical examination of family - controlled public firms. In: Family business review. 2007. vol. 20, no. 2, p. III-I26. https://doi.org/10.1III/j.174I-6248.2007.00090.x

10. CAVACO, Sandra; CHALLE, Edouard; CRIFO, Patricia; REBÉRIOUX, Antoine; ROUDAUT, Gwenaël. Board independence and operating performance: Analysis on (French) company and individual data. In: Applied economics. 2016. vol. 48, no. 52, p. 5093-5I05. https://doi.org/10.1080/00036846.2016.1170936

II. CHEN, Chia-Wei; LIN, Barry; YI, Bingsheng. CEO duality and firm performance: An endogenous issue. In: Corporate ownership and control. 2008. vol. 6, no.l, p. 58-65.

https://doi.org// 0.22495/cocv6ilp6

12. CHONG, Alberto; LOPEZ-DE-SILANES, Florêncio. Corporate governance and firm value in Mexico. In: Inter-american development bank. Research department working paper series (Inter-american development bank). 2006. https://doi.org// 0.2139/ssrn.1820043

13. CHRISTENSEN, Jacqueline; KENT, Pamela; STEWART, Jenny. Corporate governance and company performance in Australia. In: Australian accounting review. 2010. vol. 20, no. 4, p. 372-386. https://doi.org/10.1111/j.1835-2561.2010.00108.x

14. CLAESSENS, Stijn; YURTOGLU, Burcin. Corporate governance in emerging markets: A survey. In: Emerging markets review. 2013. vol. I5, p. I-33. https://doi.org/10.1016/j.ememar.2012.03.002

15. COLES, Jeffrey; NAVEEN, Daniel; NAVEEN, Lalitha. Boards: Does one size fit all?. In: Journal of financial economics. 2008. vol. 87, no. 2, p. 329-356. https://doi.org/10.1016/j.jfineco.2006.08.008

16. CORBETTA, Guido; SALVATO, Carlo. Self-serving or self-actualizing? Models of man and agency costs in different types of family firms: A commentary on "Comparing the agency costs of family and non-family firms: Conceptual issues and exploratory evidence". In: Entrepreneurship theory and practice. 2004. vol. 28, no. 4, p. 355-362. https://doi.org/10.1III/j.1540-6520.2004.00050.x

17. DAHYA, Jay; GARCIA, Laura;VAN BOMMEL, Jos. One man two hats: Whats all the commotion!. Financial review. 2009. vol. 44, no. 2, p. 179 212 . https://doi.org/10.1III/j.1540-6288.2009.00215.x

18. DAILY, Catherine; DALTON, Dan. Board of directors leadership and structure: Control and performance implications. In: 
Entrepreneurship: Theory and practice. 1993. vol. 17, no. 3, p. 65-82. https://doi.org//0.1177//104225879301700305

19. DALTON, Dan; DAILY, Catherine; ELLSTRAND, Alan; JOHNSON, Jonathan. Meta-analytic reviews of board composition, leadership structure, and financial performance. In: Strategic management journal. 1998. vol. 19, no. 3. p. 269-290.

https://doi.org//0.1002/(SICI) 1097-0266(| 99803)| 9:3<269::AIDSMJ950>3.0.CO;2-K

20. DAVIS, James; SCHOORMAN, David; DONALDSON, Lex. Toward a stewardship theory of management. In: Academy of management review. 1997. vol.22, no. I, p. 20-47. https://doi.org//0.2307/259223

21. DECHOW, Patricia; SLOAN, Richard; SWEENEY, Amy. Causes and consequences of earnings manipulation: An analysis of firms subject to enforcement actions by the SEC. In: Contemporary accounting research. 1996. vol. 13, no. I, p. I-36.

https://doi.org//0.1111/j.191I-3846.1996.tb00489.x

22. DEY,Aiyesha; ENGEL, Ellen; LIU, Xiaohui. CEO and board chair roles: To split or not to split?. In: Journal of corporate finance. 201 I. vol. 17, no. 5, p. $1595-1618$. https://doi.org/10.1016/j.jcorpfin.2011.09.001

23. DOGAN, Mesut; ELITAS, Bilge; AGCA, Veysel; ÖGEL, Serdar. The impact of CEO duality on firm performance: Evidence from Turkey. In: International journal of business and social science. 20I3. vol. 4, no. 2 , p. $149-155$.

24. DONALDSON, Lex; DAVIS, James. Stewardship theory or agency theory: CEO governance and shareholder returns. In: Australian journal of management. 1991. vol. 16, no. I, p. 49-64.

https://doi.org//0.1177/031289629101600103

25. ELSAYED, Khaled. Does CEO duality really affect corporate performance?. In: Corporate governance: An international review. 2007. vol. I5, no. 6, p. I203-12|4. https://doi.org/10.1III/j.1467-8683.2007.0064I.x

26. FALEYE, Olubunmi. Does one hat fit all? The case of corporate leadership structure. In: Journal of management \& governance. 2007. vol. II, no. 3, p. 239-259.

https://doi.org// 0.1007/s10997-007-9028-3

27. FAMA, Eugene. Agency problems and the theory of the firm. In:The journal of political economy. 1980. vol. 88, no. 2, p. 288-307. https://doi.org// 0.1086/260866

28. FAMA, Eugene; JENSEN, Michael. Separation of ownership and control. In: The journal of law \& economics. 1983. vol. 26, no. 2, p. $30 \mathrm{I}-325$.

https://doi.org// $0.1086 / 467037$

30. HANIFFA, Roszaini; HUDAIB, Mohammad. Corporate governance structure and performance of Malaysian listed companies. In: Journal of business finance \& accounting. 2006. vol. 33, no. 7-8, p. $1034-1062$. https://doi.org//0.1111/j.1468-5957.2006.00594.x
3I. HINNA, Alessandro; MONTEDURO, Fabio. Boards, governance and value creation in grant-giving foundations. In: Journal of management \& governance. 2017. vol. 21 , no. 4, p. 935-96I. https://doi.org// 0.1007/s 10997-016-9370-4

32. HUSTED, Bryan; SERRANO, Carlos. Corporate governance in Mexico. In: Journal of business ethics. 2002. vol. 37, no. 3, p. 337-348. https://doi.org/10.1023/a:1015201417632

33. JARA, Mauricio; LÓPEZ-ITURRIAGA, Félix; SAN-MARTíN, Pablo; SAONA, Paolo. Corporate governance in Latin American firms: Contestability of control and firm value. In: Business research quarterly. 2019. vol. 22, no. 4, p. 257-274. https://doi.org//0.1016/j.brq.2018.10.005

34. JENSEN, Michael; MECKLING,William. Theory of the firm: Managerial behavior, agency costs and ownership structure. In: Journal of financial economics. 1976. vol. 3, no. 4, p. 305-360. https://doi.org/10.1016/0304-405x(76)90026-x

35. JENSEN, Michael. The modern industrial revolution, exit, and the failure of internal control systems. In: The journal of finance. 1993. vol. 48 , no. 3 , p. $831-880$. https://doi.org//0.1111/j.1540-6261.1993.tb04022.x

36. JERMIAS, Johnny; GANI, Lindawati. The impact of board capital and board characteristics on firm performance. In: The british accounting review. 2014. vol. 46, no. 2, p. 135-153. https://doi.org/10.1016/j.bar.2013.12.001

37. KLAPPER, Leora; LOVE, Inessa. Corporate governance, investor protection, and performance in emerging markets. In: Journal of corporate finance. 2004. vol. 10, no. 5, p. 703-728. https://doi.org//0.1016/s0929-1199(03)00046-4

38. KRIVOGORSKY, Victoria. Ownership, board structure, and performance in continental Europe. In: The international journal of accounting. 2006. vol. 4I, no. 2, p. 176-197. https://doi.org/10.1016/j.intacc.2006.04.002

39. LAM, Tin; LEE, Shu. CEO duality and firm performance: Evidence from Hong Kong. In: Corporate governance: The international journal of business in society. 2008. vol. 18, no. 2, p. 299-316. https://doi.org//0.1108/14720700810879/87

40. LA PORTA, Rafael; LOPEZ-DE-SILANES, Florencio; SHLEIFER,Andrei; VISHNY, Robert. Agency problems and dividend policies around the world. In: The journal of finance. 2000. vol. 55, no. I, p. I-33. https://doi.org/10.1111/0022-1082.00199

4I. LA PORTA, Rafael; LOPEZ-DE-SILANES, Florencio; SHLEIFER,Andrei; VISHNY, Robert. Investor protection and corporate governance. In: Journal of financial economics. 2000. vol. 58, no.l, p. 3-27. https://doi.org//0.1016/s0304-405x(00)00065-9

42. MACHUGA, Susan; TEITEL, Karen. The effects of the Mexican corporate governance code on quality of earnings and its components. In: Journal of international accounting research. 2007. vol. 6, no. I, p. 37-55.

https://doi.org// 0.2308/jiar.2007.6.1.37 
43. MEYER, Klaus. Asian management research needs more selfconfidence. In:Asia pacific journal of management. 2006. vol. 23, n. 2, p. II9-137. https://doi.org//0.1007/s 10490-006-7/60-2

44. ORGANIZACIÓN PARA LA COOPERACIÓNY EL DESARROLLO ECONÓMICOS. Corporate governance factbook. Paris: OCDE, 2017. p. 144.

45. PENG, Mike; ZHANG, Shujun; LI, Xinchun. CEO duality and firm performance during chinas institutional transitions. In: Management and organization review. 2007. vol. 3, no. 2, p. 205-225.

https://doi.org//0.1III/j.1740-8784.2007.00069.x

46. PRICE, Richard, ROMÁN, Francisco; ROUNTREE, Brian. The impact of governance reform on performance and transparency. In: Journal of financial economics. 20I I. vol. 99, no. I, p. 76-96. https://doi.org//0.1016/.j.jineco.2010.08.005

47. PUCHETA-MARTINEZ, María. The role of the board of directors in the creation of value for the company. In: Spanish accounting review. 2015. vol. 18, no. 2, p. 148-161.

https://doi.org/10.1016/j.rcsar.2014.05.004

48. RALUCA-GEORGIANA, Moscu. Does CEO duality really affect corporate performance?. In: International journal of academic research in economics and management sciences. 2013. vol. 2, no. I, p. 156-166. http://hrmars.com/admin/pics/I522.pdf

49. RECHNER, Paula; DALTON, Dan. CEO duality and organizational performance: A longitudinal analysis. In: Strategic management journal. 1991. vol. 12, no. 2, p. 155-60. https://doi.org// 0.1002/smi.4250I20206

50. SCHILLEMANS, Thomas. Moving beyond the clash of interests: On stewardship theory and the relationships between central government departments and public agencies. In: Public management review. 2013. vol. I5, no. 4, p. 54I-562. https://doi.org//0.1080/14719037.2012.691008

5I. TANG, Jianyun. CEO duality and firm performance: The moderating roles of other executives and blockholding outside directors. In: European management journal. 2017. vol. 35, no. 3, p. 362-372. https://doi.org/10.1016/j.emj.2016.05.003

52. TUGGLE, Christopher; SIRMON, David; REUTZEL, Christopher; BIERMAN, Leonard. Commanding board of director attention: Investigating how organizational performance and CEO duality affect board members attention to monitoring. In: Strategic management journal. 2010. vol. 3I, no. 9, p. 946-968.

https://doi.org//0.1002/smj.847

53. VERA,Antonio; UGEDO, Juan. ¿Afectan las características del consejo de administración a su labor supervisora? Nueva evidencia para el mercado español. In: Revista europea de dirección y economía de la empresa. 2005. vol. 14, no. 2, p. 55-74.

54. YANG, Tina; ZHAO, Shan. CEO duality and firm performance: Evidence from an exogenous shock to the competitive environment. In: Journal of banking \& finance. 2014. vol. 49, p. 534-552. 